Ambiente \& Água - An Interdisciplinary Journal of Applied Science
ISSN 1980-993X - doi:10.4136/1980-993X
www.ambi-agua.net
E-mail: ambi.agua@gmail.com

\title{
Modeling of the potential distribution of Eichhornia crassipes on a global scale: risks and threats to water ecosystems
}

\author{
ARTICLES doi:10.4136/ambi-agua.2421
}

Received: 08 Jun. 2019; Accepted: 06 Feb. 2020

\author{
Pedro Fialho Cordeiro ${ }^{1 *(D)}$; Fernando Figueiredo Goulart ${ }^{2}{ }^{(D)}$; \\ Diego Rodrigues Macedo ${ }^{3}$; Mônica de Cássia Souza Campos $^{4}{ }^{(D}$; \\ Samuel Rodrigues Castro 5 (iD
}

\begin{abstract}
${ }^{1}$ Departamento de Cartografia. Instituto de Geociências. Universidade Federal de Minas Gerais (UFMG), Avenida Presidente Antônio Carlos, n 6627, CEP: 31270-901, Belo Horizonte, MG, Brazil

${ }^{2}$ Centro de Desenvolvimento Sustentável. Universidade de Brasília (UnB), Campus Universitário Darcy Ribeiro, Gleba A, CEP: 70.904-970, Asa Norte, Brasília, DF, Brazil. E-mail: goulart.ff@gmail.com

${ }^{3}$ Departamento de Geografia. Instituto de Geociências. Universidade Federal de Minas Gerais (UFMG), Avenida Presidente Antônio Carlos, n 6627, CEP: 31270-901, Belo Horizonte, MG, Brazil. E-mail: diegorm@ufmg.br

${ }^{4}$ Instituto SENAI de Tecnologia em Meio Ambiente. Serviço Nacional de Aprendizagem Industrial (SENAI), Avenida José Cândido da Silveira, n 2000, CEP: 31035-536, Belo Horizonte, MG, Brazil.

E-mail: mosouza@fiemg.com.br

${ }^{5}$ Departamento de Engenharia Sanitária e Ambiental. Faculdade de Engenharia. Universidade Federal de Juiz de Fora (UFJF), Rua José Lourenço Kelmer, s/n, CEP: 36036-900, Juiz de Fora, MG, Brazil.

E-mail: samuel.castro@ufjf.edu.br

*Corresponding author. E-mail: pedrofialhoc@gmail.com
\end{abstract}

\begin{abstract}
The water hyacinth (Eichhornia crassipes) is listed among the 100 worst invasive plants and was ranked as the $11^{\text {th }}$ worst invasive species in Europe, being a threat to aquatic biodiversity and water-provision. Predicting species distribution is the first step to understanding niche suitability, forecasting the invasion impact and building resilience against this species. In this study, we used a potential distribution model to assess the global risk of water hyacinth invasion by overlapping maps of highly suitable areas for water hyacinth occurrence and areas of biological importance and water scarcity. The MaxEnt - Maximum Entropy algorithm was used in the construction of the model and included five global bioclimatic layers and one of urbanized areas. Among the variables used, occurrence is mainly explained by urban areas, highlighting the importance of cities as a source or dispersion mechanism of the water hyacinth. Global biodiversity hotspots are predominantly situated in high suitability regions for the species. Ramsar sites and global protected areas are at a lower risk level compared to hotspots; however, future climate change and urban growth scenarios could put these areas at higher risk for invasion. Threats posed by the water hyacinth are possibly more acute in regions suffering from current or chronic drought. The results suggest that niche models that do not consider anthropic variables may be underestimating potential distribution of invasive species. Furthermore, the ecological plasticity of the water hyacinth and its close association with cities increase the concern about the impact of this species on the environment and on water security.
\end{abstract}

Keywords: invasive species, species distribution modeling, water hyacinth. 
Pedro Fialho Cordeiro et al.

\section{Modelagem de distribuição potencial da Eichhornia crassipes em escala global: riscos e ameaças para os ecossistemas aquáticos}

\section{RESUMO}

O aguapé é listado entre as 100 piores plantas invasoras, além de ter sido classificado como a $11^{\mathrm{a}}$ pior espécie invasora da Europa dado seu impacto na biodiversidade aquática e utilização de recursos hídricos pelas populações humanas. Prever a distribuição é o primeiro passo para entender a adequabilidade do nicho e prever o impacto da invasão pela espécie. Nesta pesquisa, um modelo de distribuição potencial do aguapé foi elaborado para avaliar o risco global de invasão, por meio da sobreposição deste modelo a áreas de biodiversidade e consumo de água. O algoritmo MaxEnt - Maximum Entropy foi utilizado na construção do modelo e incluiu cinco camadas bioclimáticas e uma de áreas urbanizadas. A camada de áreas urbanas foi a que mais contribuiu individualmente para o modelo e destacou a importância das cidades como fonte ou mecanismo de dispersão do aguapé. Os hotspots globais de biodiversidade estão predominantemente situados em regiões de alta adequabilidade para a espécie. Os sítios de Ramsar e as unidades de conservação globais estão em um nível de risco mais baixo do que os hotspots. No entanto, cenários futuros de mudanças climáticas e o crescimento urbano podem colocar essas áreas em maior risco de invasão. Ameaças provocadas pelo aguapé são possivelmente mais agudas nas regiões que sofrem com a seca crônica. Os resultados sugerem que modelos de distribuição potencial que não incluem variáveis antrópicas podem estar significativamente subestimando a distribuição potencial de espécies invasoras. Além disso, a plasticidade ecológica dessa espécie e sua associação com centros urbanos aumentam a preocupação com os impactos do aguapé na biodiversidade e sobre os recursos hídricos.

Palavras-chave: aguapé, espécies invasoras, modelos de distribuição de espécies.

\section{INTRODUCTION}

The water hyacinth (Eichhornia crassipes) is a free-floating aquatic macrophyte in the Pontederiaceae family and originates from the Brazilian Amazon (EPPO, 2008). It reproduces both vegetatively, via ramets formed from axillary buds on stolons, and sexually through seed production (EPPO, 2008). The species' growth is related to an environment's nutrient content, especially when the temperature ranges between $28^{\circ} \mathrm{C}$ and $30^{\circ} \mathrm{C}$; however, growth sharply decreases below $10^{\circ} \mathrm{C}$ or above $34^{\circ} \mathrm{C}$ (EPPO, 2008). E. crassipes colonizes still or slow-moving water bodies, such as estuarine habitats, lakes, urban areas, watercourses, and wetlands. It can tolerate water level fluctuation extremes and seasonal variations in flow velocity, as well as extremes of nutrient availability, $\mathrm{pH}$, temperature and toxic substances (Gopal, 1987).

There is currently no consensus on how and when this species was introduced into environments outside its natural habitat, but its use for ornamentation in lakes and gardens, as well as in controlling nutrients and algal blooms in eutrophic environments certainly contributed to its spread (Kriticos and Brunel, 2016). The water hyacinth is present on all continents, except Antarctica, having invaded more than 50 tropical and subtropical countries (EPPO, 2008). Due to its high dispersal and growth capacity, the species is ranked on the 100 worst invasive species list as reported by the International Union for Conservation of Nature (IUCN) and it is in the top 20 list of the Spanish Invasive Species Specialist Group (ISSG) (Téllez et al., 2008). According to Nentwig et al. (2018), E. crassipes was ranked as the $11^{\text {th }}$ worst invasive species in Europe.

Environments colonized by E. crassipes have undergone significant changes in their structure and aquatic habitat diversity, including the proliferation of disease transmitters and high fish mortality due to low concentrations of dissolved oxygen in water (Lorenzi, 2000). 
Moreover, multiple water body uses have been impacted, especially uses that affect power generation, navigation, recreation and drinking water supply (Liu et al., 2016). This effect is more pronounced in regions that suffer from chronic drought (e.g., the Mediterranean), countries with tourism-based economies (e.g., Tunisia), and countries whose principal electricity supply comes from hydroelectric generation (e.g., Brazil; Kriticos and Brunel, 2016).

In Sardinia (Italy), in 2010, the invasion of E. crassipes became evident when the Mare'eFoghe River, in the Province of Oristano, was covered for $8 \mathrm{~km}$ over an area of 560,000 $\mathrm{m}^{2}$. During this event, there was an interruption of the recreational activities that usually occur in the watercourse (Brundu et al., 2012). Countries such as Portugal, India, Sri Lanka, Bangladesh, Buma, Malaysia, Indonesia, Thailand, and the Philippines recorded negative impacts and large economic losses in rice fields of around US\$ 15 million due to E. crassipes (Moreira et al., 1999).

In some cases, the economic impacts are so significant that they require the use of control techniques, such as in the State of Florida, in the United States, which spent more than \$43 million between 1980 and 1991 on the suppression of water hyacinths. Mullin et al. (2000) reported annual expenditures for the management of the species in the order of US $\$ 500,000$ in California and 3 million in Florida. Spain spent more than 14 million euros between 2005 and 2008 to control the species in the Guadiana River Basin (Téllez et al., 2008). In Lusaka, Zambia, the E. crassipes invasion on the Kafue River led to the suspension of water treatment and the reduction of the electric power generation capacity at the Gorge Dam, for at least one week (EPPO, 2008). Hydroelectric plants in Malawi and Jinga, Uganda, on the Nile River, are also frequently affected by the turbine clogging caused by water hyacinths (Wise et al., 2007).

Given that invasive species commonly produce negative impacts, predicting which regions are at risk of biological invasions is important for developing successful monitoring programs and management strategies. In this context, Species Distribution Models (SDM) are tools used to predict the potential distribution of a particular species through the relationship between species occurrence and environmental condition data sets (Elith and Leathwick, 2009).

Many of the modeling studies which implement SDMs carried out and reported in the literature have focused on conserving and representing the distribution of rare and endemic species (Oliveira, 2011); biogeographic analyses (Whittaker et al., 2005); potential routes of infectious diseases (Peterson et al., 2006; Levine et al., 2007); predicting the effects of climate change on the geographical distribution of species (Peterson et al., 2002; Pearson et al., 2006; Wiens et al., 2009; Kriticos and Brunel, 2016); identifying priority areas for conservation (Ortega-Huerta and Peterson, 2004); and predicting the spread risks of invasive species (Peterson, 2003; Peterson and Robins, 2003; Campos et al., 2014; Kriticos and Brunel, 2016; Liu et al., 2016).

Maps generated from such models may be useful in predicting the invasive potential of exotic species, and for assessing the invasion risk in uncolonized environments (Rödder et al., 2009). We hypothesize that anthropogenic variables, such as proximity to urban areas, and climatic variables (temperature and precipitation), are determinants of the species distribution. To date, no global analyses of the potential impact of water hyacinth on biodiversity or ecosystem services have been carried out. Thus, the present study aimed to build a potential distribution model of the water hyacinth, on a global scale, in order to assess invasion risk. Additionally, the study sought to identify areas in terms of the threat level to biodiversity, water supply, and regions under chronic drought.

\section{MATERIAL AND METHODS}

\subsection{Occurrence data acquisition and processing}

The occurrence points of the species were obtained from the dataset available on the Global Biodiversity Information Facility website (GBIF - gbif.org) for the period between 1960 and 
2017. This online platform was chosen due to the ease of access to the occurrence records on a global scale, as highlighted in various recently reported studies (Syfert et al., 2013; Campos et al., 2014; Zeng et al., 2016; Liu et al., 2016). Because inconsistencies related to the reliability of the georeferencing and taxonomic identification of the water hyacinth have been identified, inconsistent registers were removed.

\subsection{Selection of environmental layers of interest}

Nineteen bioclimatic layers were obtained digitally from the WorldClim project (http://worldclim.org) at a spatial resolution $\sim 2.5$ '. In addition to these variables, a binary layer of urban areas worldwide was obtained from the Socioeconomic Data and Applications Center - SEDAC (http://sedac.ciesin.columbia.edu/data/set/grump-v1-urban-ext-polygons-rev01). This layer was considered because urban areas provide favorable conditions for the distribution of E. crassipes (Dube et al., 2018). The layers were obtained in ESRI Grid format and were converted using DIVA-GIS 7.5.0 to the ASCII format, which is compatible with the MaxEnt data entry format. ArcGIS 10.3 was used to standardize the spatial incoming data in the algorithm and to generate a Pearson correlation matrix in order to evaluate the relation between the bioclimatic variables, and thus removing the highly correlated environmental layers from the final set ( $r>|0.70|)$ (Dormann et al., 2012).

\subsection{The modeling algorithm}

The Maximum Entropy - MaxEnt v. 3.3.3 algorithm was selected to elaborate on the potential distribution model (Phillips et al., 2006). This software estimates the probability of occurrence of certain phenomena even when considering incomplete information and demonstrates excellent performance for models that only consider presence/occurrence data (Hernandez et al., 2006; Pearson et al., 2007; Wisz et al., 2008). The modeling parameters were set by default (regularization multiplier: 1; max number of background points: 10,000; replicates: 1; replicated run type: cross-validate; maximum iterations: 500; convergence threshold: 0.00001; adjust sample radius: 0). The obtained model used the best predictor variables, with $75 \%$ of the occurrence data for training and $25 \%$ for test. The environmental suitability map resulting from the model was categorized into five levels defined by the naturalbreaks function in ArcGIS 10.3. The same software was also used to represent the graphical outputs of MaxEnt.

\subsection{Model Evaluation and Validation}

In order to statistically evaluate the MaxEnt performance, analyses carried out by the software were evaluated using the Jack-Knife and the Area Under the Curve (AUC) tests. The former was carried out to evaluate the importance of the environmental layers in the explanation of the species distribution, and the latter is a statistical measure that assesses the agreement between the presence records and species distribution. An AUC value equal to 0.5 indicates that the model performance is possibly by chance similar to chance, while values closer to 1.0 indicate better model performance (Phillips et al., 2006). True Skill Statistic (TSS) was another performance measure used to evaluate the model. With values ranging from -1 to +1 , positive values closer to +1 are related to the best model performance. TSS was calculated from a confusion matrix composed of hits and misses related to the prediction of the model (Allouche et al. 2006; Tables 1 and 2).

Subsamples of 700 and 1000 records were used in order to verify if the $n$ sample size used (presence records) had a significant influence on the algorithm's performance. Moreover, an independent dataset of species occurrence ( $25 \%$ of the total records) was used for the model validation. For this process, a threshold was adopted based on Fixed Cumulative Value 5, aiming to binarize the environmental suitability map for invasion susceptibility in a presence- 
absence map of the species in order to compare the outputs of the model against actual distribution data (Phillips and Dudik, 2008).

Table 1. Confusion Matrix elaborated from the hits and misses of the model.

\begin{tabular}{lcl}
\hline & Presence & Absence \\
\hline Predicted presence & A (true positive) & B (false positive) \\
Predicted Absence & C (false negative) & D (true negative) \\
\hline
\end{tabular}

A) true positive: the model predicts the species presence and the test data confirm this statement; B) false positive: the model predicts the species presence but the test data indicate absence; C) false negative: the model predicts the species absence but the test data indicate presence; and D) true negative: the model predicts the species absence and the test data confirm this statement

Source: (Pearson et al., 2007).

Table 2. Model performance measures resulting from the confusion matrix.

\begin{tabular}{cc}
\hline Measure & Formula \\
\hline Accuracy & $\frac{A+D}{N}$ \\
Sensitivity & $\frac{A}{(A+C)}$ \\
Specificity & $\frac{D}{(B+D)}$ \\
True Skill Statistics (TSS) & (sensitivity + specificity) -1 \\
\hline
\end{tabular}

$\mathrm{N}$ : number of cases.

\subsection{Environmental impacts on areas of interest}

Eight environmental layers in ESRI shapefile (.shp) format were considered in the potential environmental impacts assessment on a global scale, such as countries (http://www.gadm.org/); drainage networks (http://www.hydrosheds.org/ download); lentic environments - ponds, lakes and dams (https://www.worldwildlife.org/ publications/); protected areas (https://www.protectedplanet.net/c/); Ramsar Sites (https://rsis.ramsar.org/); Biodiversity Hotspots (http://www.cepf.net/resources/hotspots/Pages/default.aspx); Freshwater Ecoregions of the World (http://www.feow.org/) and drylands (http://www2.unccd.int/drylandchampions). These environmental layers were overlapped with the potential distribution model and categorized according to the environmental suitability by raster zonal statistical procedure. ArcGIS 10.3 and DIVA-GIS 7.5.0 were used in the treatment of the considered environmental layers.

\section{RESULTS}

After excluding species occurrence points lacking geographic coordinates and location description or identified as duplicates, a total of 1316 occurrence points were selected to develop the model. From the records in this dataset, $62 \%$ of the points are located between the tropics $\left(23^{\circ} \mathrm{N}\right.$ and $\left.23^{\circ} \mathrm{S}\right)$, while $25 \%$ are above the Tropic of Cancer and $13 \%$ are below the Tropic of Capricorn. Thus, occurrence points are distributed across all continents, except Antarctica. Although E. crassipes is native to South America, only $22 \%$ of the occurrence 
records were on that continent, while North America accounted for about $48 \%$, Oceania with 7.7\% of the records, followed by Africa (6.1\%), Europe (5.9\%) and Asia (5.8\%).

The Pearson correlation analysis indicated a high number of correlated variables from the 19 bioclimatic layers dataset used in the model development. Six variables had no significant correlations among them $(\mathrm{r}<|0.70|)$ and thus they were selected for analysis (Dormann et al., 2012), five being bioclimatic and one being the binary layer of urban areas around the world, which was not tested with the other variables as its data has no correlation with the other layers (Table 3).

Table 3. Selected variables and Jack-Knife test result.

\begin{tabular}{cccc}
\hline Code & Variable & Percent Contribution & Permutation importance \\
\hline bio4 & Temperature Seasonality & 25.2 & 30.9 \\
bio9 & Mean Temperature of Driest Quarter & 20.7 & 31.5 \\
bio13 & Precipitation of Wettest Month & 18.2 & 13.1 \\
bio14 & Precipitation of Driest Month & 8.1 & 12.6 \\
bio15 & Precipitation Seasonality (CV*) & 1.3 & 1.9 \\
urb_ext & Urban extent & 26.5 & 10 \\
\hline
\end{tabular}

* Coefficient of Variation.

According to the Jack-Knife test, "urban extent" and "temperature seasonality" variables individually contributed the most to the model. The developed model used 987 training points and 329 test points, performing better than expected at random model (AUC $=0.917$ and TSS $=0.70$ ). The result of the sensitivity statistical measure was higher than the specificity, indicating that the model produced few errors of omission (Syfert et al., 2013; Table 4). Additional tests were performed using 1000 and 700 records to evaluate the efficiency of the model when using subsamples, which verified that the reduction of the $n$ sample size causes few changes in the model performance with hit rates higher than $93 \%$ in all cases.

Table 4. Model performance measures.

\begin{tabular}{lccc}
\hline & \multicolumn{3}{c}{ Number of samples } \\
\hline & $\mathbf{1 3 1 6}$ & $\mathbf{1 0 0 0}$ & $\mathbf{7 0 0}$ \\
\hline Threshold* $^{*}$ & 0.145 & 0.118 & 0.122 \\
AUC & 0.917 & 0.926 & 0.936 \\
TSS & 0.70 & 0.69 & 0.67 \\
Overall accuracy & 0.743 & 0.746 & 0.778 \\
Sensitivity & 0.963 & 0.946 & 0.892 \\
Specificity & 0.738 & 0.743 & 0.777 \\
Hit rate (\%) & 96.35 & 95.60 & 93.14 \\
\hline
\end{tabular}

*Fixed cumulative value 5.

The modeled distribution is consistent with the actual points of species occurrence used in this study, as well as administrative regions in which the water hyacinth has established populations, either in their native or non-native habitats (Figure 1). The model indicated a broad spectrum of potential environments that could be invaded by the E. crassipes and then the binarized distribution model transformed the results of the environmental suitability map into a presence/absence map (Figure 2).

According to the results, E. crassipes could be affecting the storage and freshwater supply in Central America, the Southeastern United States, Africa (Sub-Saharan Africa), Southern Europe, Southern and Southeastern Asia, and Oceania (note that more field data is required for confirmation). It should be highlighted that more than $33 \%$ of the main watercourses and $10 \%$ 
of the entire area of the world's lentic environments occur in regions that are suitable for the species occurrence. Approximately $44 \%$ of the world's lentic environments present conditions for colonization. For many tropical countries located in identified risk areas, almost all of their important watercourses are located in regions of high suitability (supplementary material Table A: http://doi.org/10.5281/zenodo.3708474).

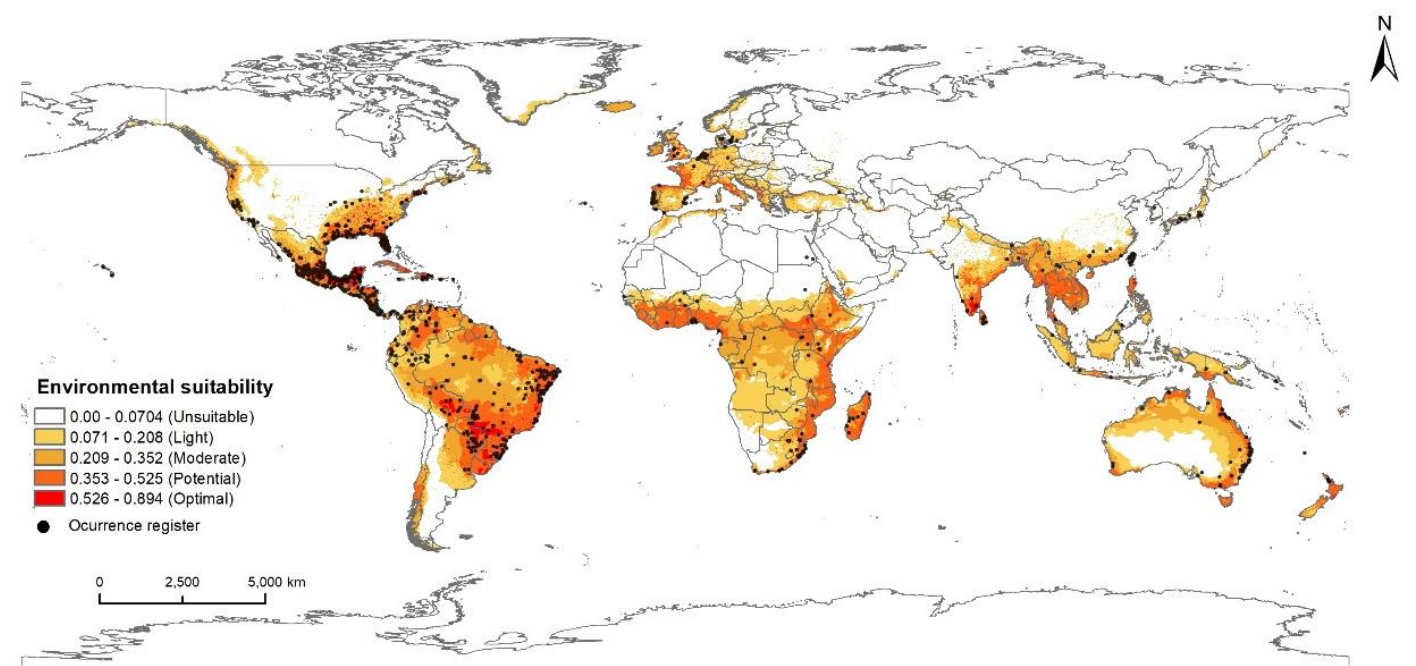

Figure 1. Modeled potential distribution of E. crassipes on a global scale by countries.

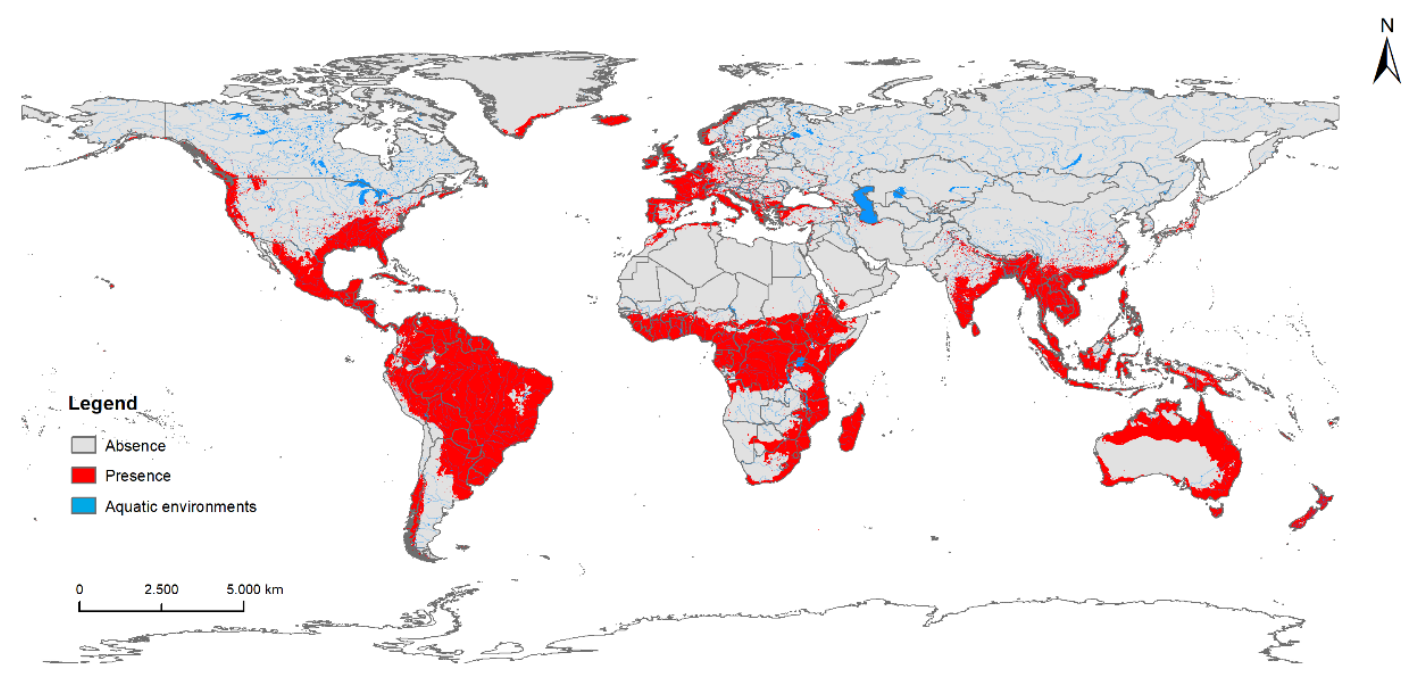

Figure 2. Presence/absence map of E. crassipes on a global scale.

Many global ecoregions are under threat since more than $43 \%$ of global river basins present ideal conditions for invasion risk. There are many basins located in both North and South America with a high degree of fish species endemism that also offers the highest suitability for invasion (see http://www.feow.org) (supplementary material - Table B: http://doi.org/10.5281/zenodo.3708474). (Figure 3).

About $52 \%$ of the Protected Areas (PA) of the world are under potential conditions for the establishment of E. Crassipes. Less than $1 \%$ of PAs are located in optimum conditions, corresponding to more than $279,551 \mathrm{~km}^{2}$ of areas that can be or are already invaded. On the other hand, approximately $48 \%$ of the total land area of PAs lies outside of regions that offer water hyacinth suitability (Table 5). These PAs are predominantly either above the Tropic of Cancer or below the Tropic of Capricorn. Some of them are among the largest PAs on the planet, such as the Greenland biosphere reserve and the Chinese natural reserves of Sanjiangyuan and Qiangtang. 


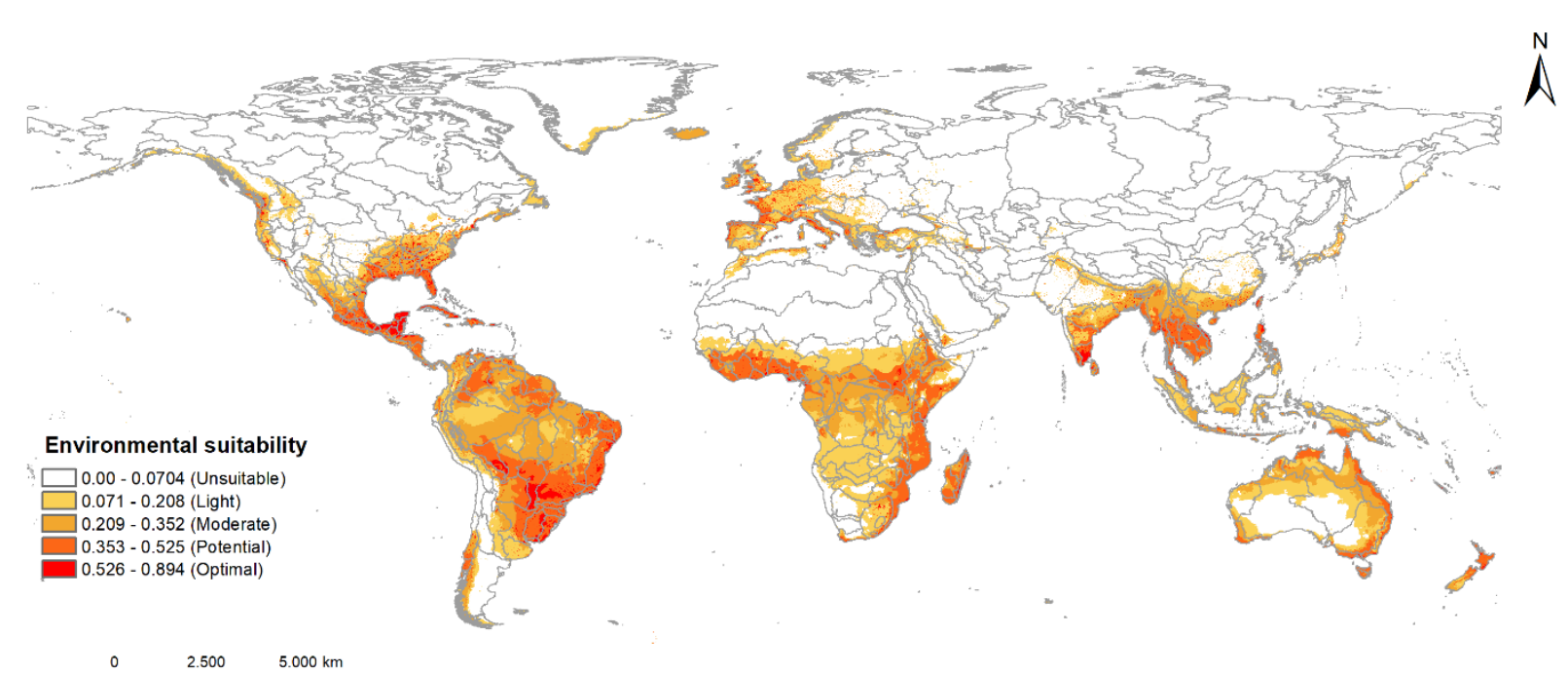

Figure 3. Modeled potential distribution of E. crassipes on a global scale by world freshwater ecoregions.

Approximately $28 \%$ of the world's biodiversity hotspot areas are located in regions of high suitability, while $6 \%$ are in optimal conditions for the occurrence of the water hyacinth. When considering the threshold adopted in the model, $79 \%$ of the global biodiversity hotspot areas can be invaded. There are large areas of potentially threatened hotspots in Mexico, the Southeastern United States, Brazil, Madagascar, and tropical Asia (Figure 4). About $50 \%$ of Ramsar sites are in places that offer minimum conditions of suitability for the occurrence of the water hyacinth. Approximately $3 \%$ of the area of the sites or 67.6 thousand $\mathrm{km}^{2}$ occur in optimal conditions and $18 \%$ are in places of high suitability (Table 5). The projected distribution indicates a high likelihood of species expansion including newly established Ramsar sites.

Table 5. Quantitative results of environmental suitability in PAs, biodiversity hotspots and global Ramsar sites.

\begin{tabular}{cccccccc}
\hline & & \multicolumn{2}{c}{ Protected Areas } & \multicolumn{2}{c}{ Biodiversity Hotspots } & \multicolumn{2}{c}{ Ramsar Sites } \\
\hline Class & Values & $\begin{array}{c}\text { Area } \\
(\text { Sq. Km) }\end{array}$ & Area & $\begin{array}{c}\text { Area } \\
(\mathbf{S q} . \mathbf{K m})\end{array}$ & Area & $\begin{array}{c}\text { Area } \\
(\mathbf{S q} . \mathbf{K m})\end{array}$ & Area \\
\hline 1 & $0-0.07$ (Unsuitable) & $9,512,898$ & $48 \%$ & $6,818,674.62$ & $21 \%$ & $1,104,518.51$ & $50 \%$ \\
2 & $0.071-0.208$ (Light) & $3,811,932$ & $19 \%$ & $6,480,462.70$ & $20 \%$ & $315,576.72$ & $14 \%$ \\
3 & $0.209-0.352$ (Moderate) & $3,677,078$ & $18 \%$ & $7,788,311.41$ & $25 \%$ & $338,117.91$ & $15 \%$ \\
4 & $0.353-0.525$ (Potential) & $2,698,951$ & $14 \%$ & $8,692,197.84$ & $28 \%$ & $405,741.49$ & $18 \%$ \\
5 & $0.526-0.894$ (Optimal) & 279,551 & $1 \%$ & $1,984,467.17$ & $6 \%$ & $67,623.58$ & $3 \%$ \\
\hline & Total & $19,980,411$ & $100 \%$ & $31,764,113.75$ & $100 \%$ & $2,231,578.21$ & $100 \%$ \\
\hline
\end{tabular}

Approximately $30 \%$ of the world's drylands are under potential risk of colonization, such as the in the Southwestern United States, Central-East and Southern Africa, Northern Asia, Northeastern Brazil, and Australia. Almost $50 \%$ of the available water resources in dry and subhumid lands are potentially threatened (Figure 5 and Table 6). 


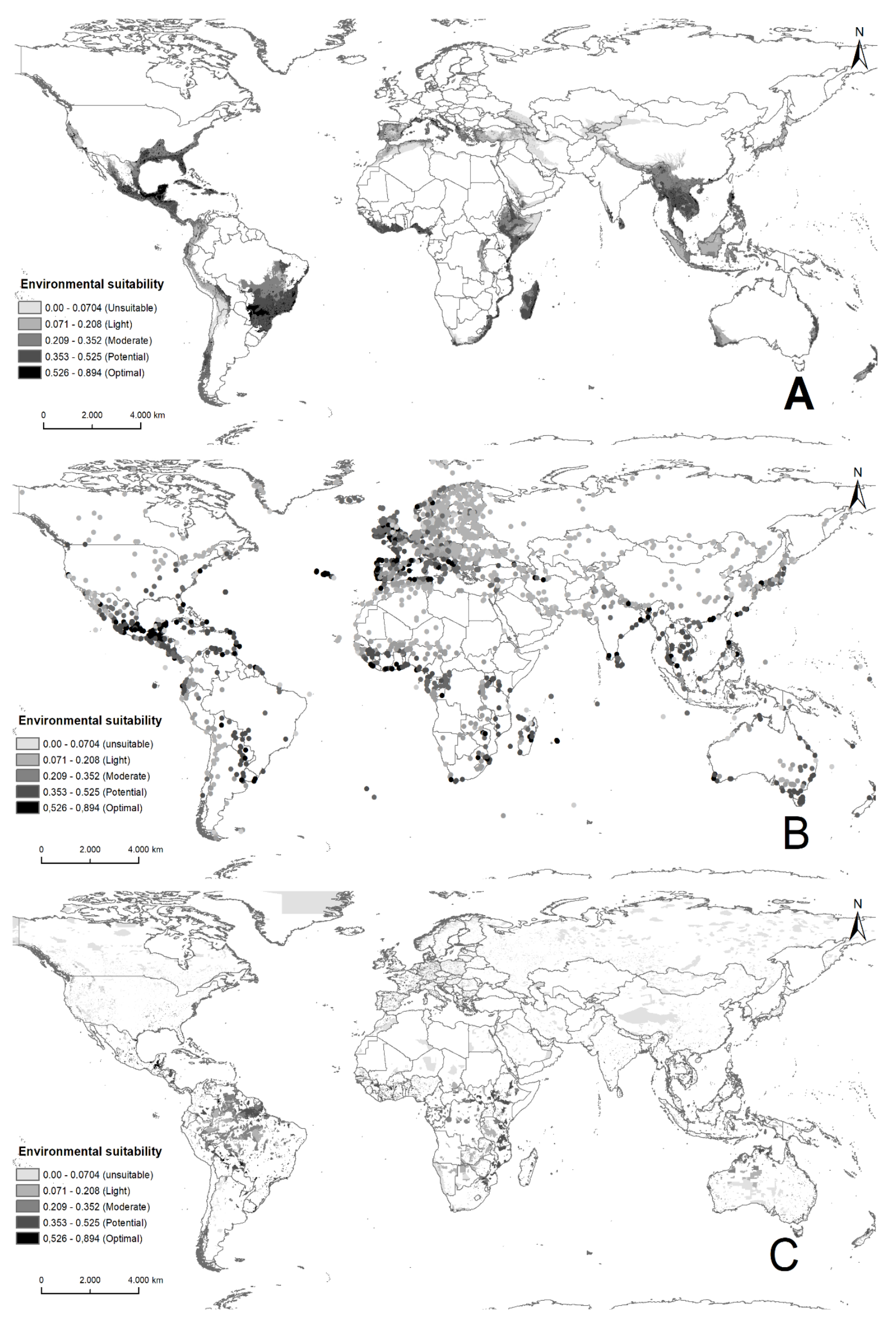

Figure 4. Environmental suitability of E. crassipes by (A) Biodiversity Hotspots, (B) Ramsar sites and (C) Protected Areas. 


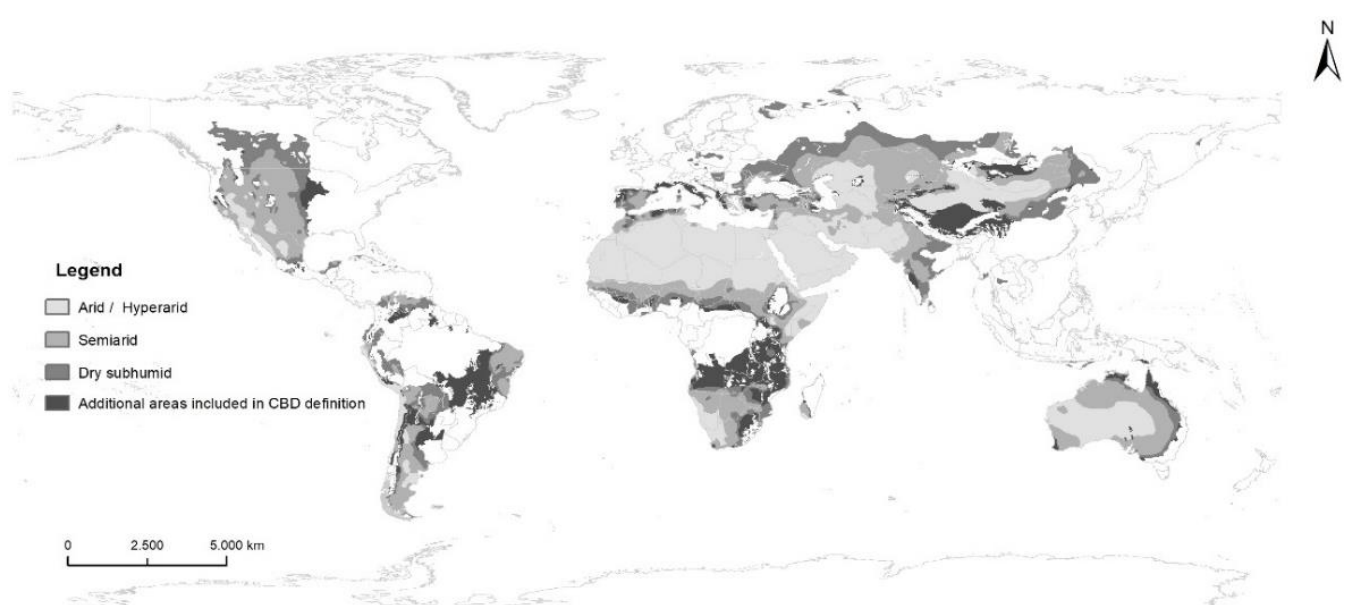

A

Figure 5. United Nations Convention to Combat Desertification (UNCC) and Convention on Biological Diversity (CBD) drylands.

Table 6. Quantitative results of environmental suitability in drylands.

\begin{tabular}{ccccccccc}
\hline Drylands & Area $($ Sq. Km) & Min & Max & Range & Mean & STD & Sum & Rate \\
\hline Semiarid & $22,649,806$ & 0.0000 & 0.8788 & 0.8788 & 0.1127 & 0.1415 & $166,897.85$ & 0.0074 \\
Dry sub humid & $13,060,855$ & 0.0000 & 0.8732 & 0.8732 & 0.1627 & 0.1802 & $138,955.59$ & 0.0106 \\
Additional areas included in & $10,778,305$ & 0.0000 & 0.8705 & 0.8705 & 0.1982 & 0.1730 & $139,715.69$ & 0.0130 \\
CBD definition & $15,669,497$ & 0.0000 & 0.8514 & 0.8514 & 0.0383 & 0.0777 & $39,220.17$ & 0.0025 \\
Arid / Hyperarid & &
\end{tabular}

Min: lower suitability value; Max: highest suitability value; Range: difference between the lowest and the highest value; Mean: average suitability value; STD: standard deviation; Sum: sum of the values of the pixels of suitability; Rate: sum of the pixel values divided by the area.

\section{DISCUSSION}

We confirmed the hypothesis that both climatic and anthropic layers are important predictors for water hyacinth distribution. Our analyses showed that the distribution of $E$. crassipes is limited by low temperatures at high altitudes and latitudes, as well as by heat and aridity in desert regions in Africa, Australia, Chile, Argentina, and Asia. In contrast to the Northern Hemisphere, the Southern Hemisphere has few areas that are cold enough to prevent species establishment. There is little opportunity for E. crassipes to expand the boundaries of its occupation beyond the habitats already colonized in the southern hemisphere, given that the Andes Cordillera in South America and the desert lands of Australia constitute a stress gradient due to the cold and arid conditions, respectively.

We also found significant overlap amongst highly suitable regions for species occurrence and areas of water scarcity and biologically important regions. World Protected Areas (PAs) are less threatened than Ramsar sites and Biodiversity Hotspots, considering water hyacinth suitability. The results obtained for the PAs were significantly influenced by the large number of PAs located in Asia and at high latitudes, which are not suitable for the species. The Ramsar sites are in an intermediate invasion potential condition. Despite this, the projected distribution indicates a high probability of expansion of the species to newly established Ramsar sites, such as the Marais de Sacy, in France; Lake Massaciuccoli, in the region of Tuscany, Italy; and the environmental protection area of Cananéia-Iguapé-Peruíbe, in São Paulo, Brazil. Global biodiversity hotspots showed alarming results. Approximately $79 \%$ of their areas are within suitable conditions for the occurrence of the water hyacinth since the most biodiverse regions of the world are concentrated in the tropics, the portion of the planet where the water hyacinth is predominant. 
Threats posed by this species are possibly more acute in regions suffering from chronic drought or drought. In countries such as Greece, Albania, Macedonia, Bosnia, and Croatia, which have an extremely dry summer period and where available water resources are essential for human survival. Thus, in these locations, the environmental and economic impacts can be much more serious.

Threshold selection (fixed cumulative value 5) aimed to reduce the percentage of omission errors, because the modeled species is a generalist, being able to find adequate conditions for its survival throughout the projected area of occupation (Norris, 2014). The tests performed with this threshold, with subsamples of 1000 and 700 registers, showed that the reduction of the sample size implies a small reduction in the performance of the model. In all cases, the accuracy was higher than $93 \%$. Despite this, there was a small reduction in accuracy from $96 \%$ to $93 \%$, due to the decrease in the independent set of data used in the validation (Zhang et al., 2015). The model presented good performance, obtaining an AUC of 0.917. However, in some cases, the use of this statistical measure is criticized (Allouche et al., 2006). In addition, the True Skill Statistics (TSS $=0.70$ ) was calculated, which confirmed the good AUC result.

Urban areas had a major influence on the projected distribution of the water hyacinth, which based on our analysis was the most influential factor explaining water hyacinth occurrence. This highlights the importance of cities serving as the source locations of hyacinth propagules due to the high levels of water pollution that contribute to species colonization. Moreover, cities serve as global dispersion vectors as they facilitate the spread of the water hyacinth far beyond its original distribution range. Due to the close association between the species and urban areas, coupled with its wide niche suitability, from the conservation and management point of view increases concern about the current and future impacts of the water hyacinth.

Results obtained by Gallardo et al. (2015) corroborate our findings, as their study indicates the importance of anthropic variables in the construction of SDMs by showing that anthropic variables explained a substantial amount (23\% on average) of species distributions. Megacities, which are developing mainly in Asia, may accentuate the potential for invasion of the water hyacinth on that continent. In Europe, Rodríguez-Merino et al. (2017) showed that the best predictor of potential distribution for the majority of non-native aquatic macrophytes was the human footprint. In addition, the most vulnerable areas are located near to the sea and the high population density cities. An important part of the areas for colonization of these species coincide with territories with agricultural development increase.

Our projected distribution on the European continent suggests a much wider range than that found by Kriticos and Brunel (2016), who did not include urbanized areas in their model. Moreover, our projected distribution in South Africa also suggests a larger area at invasion risk, under current climatic conditions, than the areas identified by Hoveka et al. (2016), who also did not include anthropic related variables in their model.

One limitation of this study refers to the small number of occurrence records obtained from the GBIF portal for South America. This limitation could be improved using other platforms that provide more information on the distribution of the species. Nevertheless, automatically reducing occurrence numbers had little effect on models' performance, which suggests that the number of records were sufficient to test our hypothesis and strengthen the results.

Another limitation is collector's bias, as in general, most sampled areas are those of greater economic interest or more easily accessible, such as protected areas or near cities, roads and rivers (Oliveira, 2011; Norris, 2014). The use of more records would probably improve model performance. Nevertheless, although it is possible to measure collectors' bias, it is not possible to get rid of it, and virtually all niche models have such bias. Finally, water specific variables, which are extremely important for the water hyacinth occurrence, were not used in our SDM because no reliable data is currently available on a global scale. 


\section{CONCLUSIONS}

The present study consisted of the elaboration of a potential distribution model of the water hyacinth on a global scale. Risk areas were identified in terms of threats to habitat biodiversity, water supply, and chronic drought. The results of this model are consistent with the distribution of collected occurrence records. They can also be used to predict the distribution of the target species at a broad geographic scale for areas where no samples were collected, which can serve to complement and direct costly field surveys. Thus, the most vulnerable areas can be understood, directing quick response efforts.

Global biodiversity hotspots are predominantly situated in regions of high environmental suitability. Ramsar sites and global protected areas are in a more secure status, but climate change scenarios and the growth of urban areas may put them at risk of invasion. A more detailed and individual evaluation for each of these areas is suggested in order to categorize them according to their environmental suitability for invasion susceptibility and proximity to recorded E. crassipes locations. Furthermore, we recommend that SDMs should use anthropogenic layers to better represent species distribution.

From the methodological point of view, this work adds to the literature as it brings evidence that modeling invasive species niches needs to include anthropic layers as explanatory variables, otherwise potential distribution may be underestimated. In this case, more than one quarter of the hyacinth occurrence is explained by the presence of urban centers, greatly expanding the range of areas identified as highly suitable when compared to previous studies that only relied on bioclimatic conditions to model the occurrence of this species.

From the conservation and water security point of view, we demonstrate that the water hyacinth should occur in areas around the globe where humidity and heat levels are appropriate. Given increasing rates of urbanization, particularly in tropical and developing countries (D'Amour et al., 2017), these and surrounding areas provide ideal environments for water hyacinth occurrence. Such findings increase the concern of the current and future impact of this plant on aquatic biodiversity and water resources.

Finally, understanding the full invasion potential of this species is crucial for decisions that involve species management and to avoid negative impacts. The methodology used in this study could be used in evaluating the dispersion potential of other invasive species.

\section{ACKNOWLEDGMENTS}

Diego Rodrigues Macedo was supported by CNPq (402907/2016-7), PPGs-UFMG Geografia and Análise e Modelagem de Sistemas Ambientais (Capes Finance Code 001), P\&D ANELL (GT599). Fernando Figueiredo Goulart received a PNPD scholarship (Finance Code 001) from the Coordenação de Aperfeiçoamento de Pessoal de Ensino Superior-CAPES.

\section{REFERENCES}

ALLOUCHE, O.; TSOAR, A.; KADMON, R. Assessing the accuracy of species distribution models: prevalence, kappa and the true skill statistic (TSS). Journal of Applied Ecology, v. 43, p.1223-1232, 2006. https://dx.doi.org/10.1111/j.1365-2664.2006.01214.x

BRUNDU, G.; STINCA, A.; ANGIUS, L.; BONANOMI, G.; CELESTI-GRAPOW, L.; D'AURIA, G. Pistia Stratiotes L. and Eichhornia crassipes (Mart.) Solms.: emerging invasive alien hydrophytes in Campania and Sardinia (Italy). Bulletin OEPP/EPPO Bulletin, v. 42, n. 568-579, 2012. https://dx.doi.org/10.1111/epp.12004 
CAMPOS, M. C. S.; ANDRADE, A. F. A.; KUNZMANN, B.; GALVÃO, D. D.; SILVA, F. A.; CARDOSO, A. V.; CARVALHO, M. D.; MOTA, H. R. Modelling of the potential distribution of Limnoperna fortunei (Dunker, 1857) on a global scale. Aquatic Invasions, v. 9, p. 253-265, 2014. http://dx.doi.org/10.3391/ai.2014.9.3.03

D’AMOUR, C. B.; REITSMA, F.; BAIOCCHI, G.; BARTHEL, S.; GÜNERALP, B.; ERB, K.; HARBEL, H.; CREUTZIG, K.; SETO, K. C. Future urban land expansion and implications for global croplands. Proceedings of the National Academy of Sciences, v. 114, n. 34, p. 8939-8944, 2017. https://doi.org/10.1073/pnas.1606036114

DORMANN, C. F.; ELITH, J.; BACHER, S.; BUCHMANN, C.; GUDRUN, C. G.; GARCÍA MARQUÉZ, J. R.; GRUBER, B.; LAFOURCADE, B.; LEITÃO, P. J.; MÜNKEMÜLLER, T.; MCCLEAN, C.; OSBORNE, P. E.; BJÖRN, R.; SCHRÖDER, B.; SKIDMORE, A. K.; ZURELL, D.; LAUTENBACH, S. Collinearity: a review of methods to deal with it and a simulation study evaluating their performance. Ecography, v. 35, p. 001-020, 2012. https://doi.org/10.1111/j.1600-0587.2012.07348.x

DUBE, T.; SIBANDA, M.; BANGAMWABO, V.; SHOKO, C. Establishing the link between urban land cover change and the proliferation of aquatic hyacinth (Eichhornia crassipes) in Harare Metropolitan, Zimbabwe. Physics and Chemistry of the Earth, v. 108, p. 1927, 2018. https://doi.org/10.1016/j.pce.2018.09.010

ELITH, J.; LEATHWICK, J. R. Species distribution models: ecological explanation and prediction across space and time. Annual Review of Ecology, Evolution and $\begin{array}{llllll}\text { Systematics, } & \text { v. } & 40, & \text { p. } & 677-697, & 2009 .\end{array}$ https://doi.org/10.1146/annurev.ecolsys.110308.120159

EPPO. Eichhorniacrassipes. Bulletin OEPP/EPPO Bulletin, v. 38, p. 441-449, 2008.

GALLARDO, B.; ZIERITZ, A.; ALDRIDGE, D. C. The importance of the human footprint in shaping the global distribution of terrestrial, freshwater and marine invaders. PLOS One, v. 10, n. 8, p. 1-17, 2015. https://doi.org/10.1371/journal.pone.0125801

GOPAL, B. Water Hyacinth. Amsterdam: Elsevier, 1987.

HERNANDEZ, P. A.; GRAHAM, C. H.; LAWRANCE, L.; MASTER, A. N. D.; DEBORAH, L. A. The effect of sample size and species characteristics on performance of different species distribution modeling methods. Ecography, v. 29, p. 773-785, 2006. https://doi.org/10.1111/j.0906-7590.2006.04700.x

HOVEKA, L. N.; BEZENG, B. S.; YESSOUFOU, J. S.; VAN DER BANK, M. Effects of climate change on the future distributions of the top five freshwater invasive plants in South Africa. South African Journal of Botany, p. 33-38, 2016. https://doi.org/10.1016/j.sajb.2015.07.017

KRITICOS, D. J.; BRUNEL, S. Assessing and managing the current and future pest risk from water hyacinth (Eichhornia crassipes), an invasive aquatic plant threatening the environment and water security. PLOS One, v. 11, n. 8, p. 1-18, 2016. https://doi.org/10.1371/journal.pone.0120054

LEVINE, R. S.; PETERSON, A. T.; YORITA, K. L.; CARROLL, D.; DAMON, I. K.; REYNOLDS, M. G. Ecological niche and geographic distribution of human monkeypox in Africa. Plos One, v. 2, p. 1-7, 2007. https://doi.org/10.1371/journal.pone.0000176

LIU, D.; WANG, R.; GORDON, D. R.; SUN, X.; CHEN, L.; WANG, Y. Predicting plant invasions following china's water diversion project. Environmental Science \& Technology, v. 51, n. 3, p. 1450-1457, 2016. https://doi.org/10.1021/acs.est.6b05577 
LORENZI, H. Plantas Daninhas do Brasil: terrestres, aquáticas, parasitas e tóxicas. 3. ed. Nova Odessa: Instituto Plantarum, 2000.

MOREIRA, I.; FERREIRA, T.; MONTEIRO, A.; CATARINA, L.; VASCONCELOS, T. Aquatic weeds and their management in Portugal: insights and the international context. Hydrobiologia, v. 415, p. 229-234, 1999. https://doi.org/10.1007/978-94-017-09224_32

MULLIN, B. H.; ANDERSON, L. W. J.; DITOMASO, J. M.; EPLEE, R. E.; GETSINGER, K. D. Invasive plant species. Council for Agricultural Science and Technology, n. 13, 2000 .

NENTWIG, W.; BACHER, S.; KUMSCHICK, S.; PYŠEK, P.; VILÀ, M. More than "100 worst" alien species in Europe. Biological Invasions, v. 20, n. 6, p. 1611-1621, 2018. https://doi.org/10.1007/s10530-017-1651-6

NORRIS, D. Model thresholds are more important than presence location type: understanding the distribution of lowland tapir (Tapirusterrestris) in a continuous Atlantic forest of southeast Brazil. Tropical Conservation Science, v. 7, n. 3, p. 529-547, 2014. https://doi.org/10.1177/194008291400700311

OLIVEIRA, U. Diversidade e Biogeografia de Aranhas do Brasil: Esforço Amostral, Riqueza Potencial e Áreas de Endemismo. 2011. 103 f. Tese (Doutorado) Universidade Federal de Minas Gerais, Belo Horizonte, 2011.

ORTEGA-HUERTA, M. A.; PETERSON, A. T. Modelling spatial patterns of biodiversity for conservation prioritization in North-eastern Mexico. Diversity and Distributions, v. 10, p. 39-54, 2004. https://doi.org/10.1111/j.1472-4642.2004.00051.x

PEARSON, R. G. C.; THUILLER, W.; ARAÚJO, M. B.; MARTINEZMEYER, E.; BROTONS, L.; MCCLEAN, C. MILES, L.; SEGURADO, P.; DAWSON, T. C.; LEES, D. C. Model based uncertainty in species range prediction. Journal of Biogeography, $v$. 33, p. 1704- 1711, 2006. https://doi.org/10.1111/j.1365-2699.2006.01460.x

PEARSON, R. G. C.; RAXWORTHY, J.; NAKAMURA, M.; PETERSON, A. T. Predicting species distributions from small numbers of occurrence records: a test case using cryptic geckos in Madagascar. Journal of Biogeography, v. 34, p. 102-117, 2007. https://doi.org/10.1111/j.1365-2699.2006.01594.x

PETERSON, A. T. Predicting the geography of species' invasions via ecological niche modeling. The Quarterly Review of Biology, v. 78, p. 419-433, 2003. https://doi.org/10.1086/378926

PETERSON, A. T.; ROBINS, C. R. Using ecological niche modeling to predict Barred Owl invasions with implications for Spotted Owl conservation. Conservation Biology, v. 17, p. 1161-1165, 2003. https://doi.org/10.1046/j.1523-1739.2003.02206.x

PETERSON, A. T.; LASH, R. R.; CARROLL, D. S.; JOHNSON, K. M. Geographic potential for outbreaks of Marburg hemorrhagic fever. American Journal of Tropical Medicine and Hygiene, v. 75, p. 9-15, 2006. https://doi.org/10.4269/ajtmh.2006.75.1.0750009

PETERSON, A. T.; ORTEGA-HUERTA, M. A.; BARTLEY, J.; SÁNCHEZ-CORDERO, V.; SOBERÓN, J.; BUDDEMEIER, R. H.; STOCKWELL, D. R. B. Future projections for Mexican faunas under global climate change scenarios. Nature, v. 416, p. 626-629, 2002. https://doi.org/10.1038/416626a 
PHILLIPS, S. J. R. P.; ANDERSON, R.; SCHAPIRE, E. Maximum entropy modeling of species geographic distributions. Ecological Modelling, v. 190, p. 231-259, 2006. https://doi.org/10.1016/j.ecolmodel.2005.03.026

PHILLIPS, S. J.; DUDIK, M. Modelling of species distributions with MaxEnt: new extensions and a comprehensive evaluation. Ecography, v. 31, p. 161-175, 2008. https://doi.org/10.1016/j.ecolmodel.2005.03.026

RÖDDER, D.; SCHMIDTLEIN, S.; VEITH, M.; LOTTERS, S. Alien Invasive Slider Turtle in Unpredicted Habitat: A Matter of Niche Shift or of Predictors Studied? PlosOne, v. 4, n. 11, p. 1-9, 2009. https://doi.org/10.1371/journal.pone.0007843

RODRÍGUEZ-MERINO, A.; FERNÁNDEZ-ZAMUDIO, R.; GARCÍA-MURILLO, P. An invasion risk map for non-native aquatic macrophytes of the Iberian Peninsula. Anales Del Jardín Botánico de Madrid, v. 74, n. 1, p. 1-10, 2017. https://doi.org/10.3989/ajbm.2452

SYFERT, M. M.; SMITH, M. J.; COOMES, D. A. The effects of sampling bias and model complexity on the predictive performance of Maxent species distribution models. PLoS ONE, v. 8, n. 2, p. e55158, 2013. https://doi.org/10.1371/journal.pone.0055158

TÉLLEZ, T. R.; LÓPEZ, E.; GRANADO, G. L.; PÉREZ, E. A.; LÓPEZ, R. M.; GUZMÁN, J. M. S. The Water hyacinth, Eichhornia crassipes: an invasive plant in the Guadiana River Basin (Spain). Aquatic Invasions, v. 3, p. 42-53, 2008. https://doi.org/10.3391/ai.2008.3.1.8

WIENS, J. A.; STRALBERG, D.; JONGSOMJIT, D.; HOWELL, C. A.; SNYDER, M. A. Niches, models, and climate change: assessing the assumptions and uncertainties. Proceedings of the National Academy of Sciences of the United States of America, v. 106, p. 19729-19736. 2009. https://doi.org/10.1073/pnas.0901639106

WISE, R. M.; WILGEN, B. W.; HILL, M. P.; SCHULTHESS, F.; TWEDDLE, D.; CHABIOLAY, A. The economic impact and appropriate management of selected invasive alien species on the African continent. Global Invasive species Programme. CSIR Report No. CSIR/NRE/RBSD/ER/2007/0044/C. Feb. 2007. Available at: http://www.issg.org/pdf/publications/GISP/Resources/CSIRAISmanagement.pdf. Access: Feb. 2020.

WISZ, M. S.; HIJMANS, R. J.; LI, J.; PETERSON, A.T.; GRAHAM, C. H.; GUISAN, A. E. Predicting species distributions working group. Effects of sample size on the performance of species distribution models. Diversity and Distributions, v. 14, p. 763-773, 2008. https://doi.org/10.1111/j.1472-4642.2008.00482.x

WHITTAKER, R. J.; ARAUJO, M. B.; PAUL, J.; LADLE, R. J.; WATSON, J. E. M; WILLIS, K. J. Conservation biogeography: assessment and prospect. Diversity and Distributions, v. 11, p. 3-23, 2005. https://doi.org/10.1111/j.1366-9516.2005.00143.x

ZENG, Y.; LOW, B. W.; DARREN, C., J., Y. Novel methods to select environmental variables in MaxEnt: A case study using invasive crayfish. Ecological Modelling, p. 5-13, 2016. https://doi.org/10.1016/j.ecolmodel.2016.09.019

ZHANG, L.; LIU, S.; SUN, P.; WANG, T.; WANG, G.; ZHANG, X. Consensus forecasting of species distributions: the effects of niche model performance and niche properties. PLoS ONE, v. 10, n. 3, p. e0120056, 2015. https://doi.org/10.1371/journal.pone.0120056 